\title{
HAYEK'S THE SENSORY ORDER AND GADAMER'S
}

PhenOMENOLOgICAL HERMENEUTICS

BY FRANCESCO DI IORIO

CHOPE Working Paper No. 2013-10

July 2013

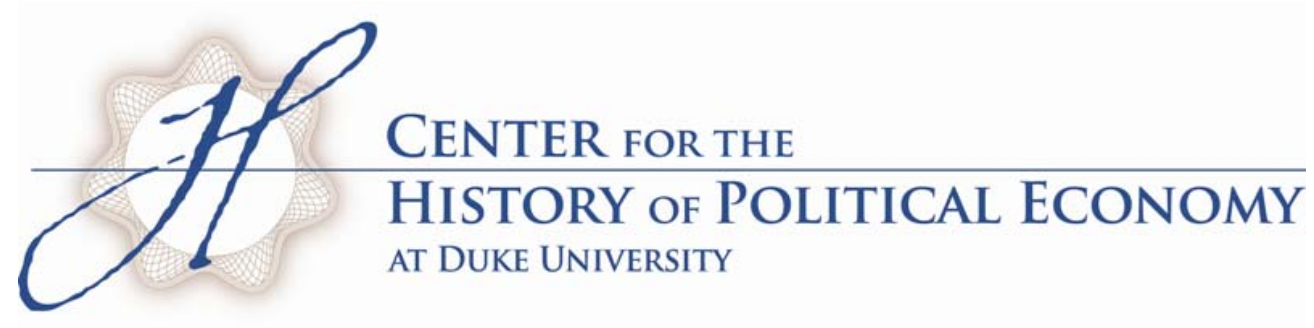


Francesco Di Iorio

\title{
Hayek's The Sensory Order and Gadamer's Phenomenological Hermeneutics
}

"[T]here was a lot more at stake in The Sensory
Order than might at first appear evident."

Bruce Caldwell

\begin{abstract}
This article reinterprets Hayek's cognitive psychology from the standpoint of the categories employed by phenomenological hermeneutics, and notably by Gadamer. Both Hayek and Gadamer agree on the idea that consciousness is the outcome of a process of interpretation that depends on a 'shifting horizon' - a hermeneutical horizon that is the product of history and that is subject to a constant evolution over time. By comparing Hayek's anti-objectivistic psychology with Gadamer's view, it is possible to clarify and enrich Hayek's distributed knowledge paradigm as well as his criticism of the mechanistic and deterministic theories of action.
\end{abstract}

Keywords: Hayek, Gadamer, Hermeneutics, Self-Organizing Mind, Methodological Individualism.

\section{Introduction}

As it is well known, Hayek largely focused on the concepts of social complexity and unintended consequences, while he did not write extensively about the epistemology of action. Due to this fact, his methodological individualism has often been accused of being characterized by a gap (see, for instance, Boudon 2005). Although this criticism may be understandable, it is partly unfair because Hayek devoted an entire book to the study of action, The Sensory Order. This book is rarely quoted because it analyses action from a neurophysiological angle and thus is not easy to read. This paper attempts to clarify the relevance of Hayek's cognitive psychology for 
the epistemology of action and the methodology of social sciences. It tries to make the philosophical implications of The Sensory Order clear and also to explain why this book is important to understanding Hayek's thought.

We will maintain that The Sensory Order proposes a theory of knowledge and action that is consistent with the core of Gadamer's hermeneutical philosophy. We will also argue that, for this reason, The Sensory Order provides an analysis of the cognitive presuppositions of the concept of unintended consequences. Although Hayek never quotes Gadamer and other theorists of hermeneutics, he maintains in practice that a human being is an interpreter in the sense of hermeneutics. As Lachmann (1977; 2007) pointed out, hermeneutics is an old philosophical tradition that matches up well the verstehen perspective of the Austrian School's methodological individualism.

A number of authors have suggested that a similarity exists between Hayek's and Gadamer's theories of knowledge (see, for instance, Lavoie 1991). Moreover, some of them also stressed that Hayek's cognitive psychology is a defence of verstehen in the social sciences (see Boettke 1990; Butos and Koppl 2006; Caldwell 2004; Koppl 2008; 2010). However, there has thus far been no attempt made to analyse Hayek's connectionist theory of consciousness in the light of the categories that are employed in phenomenological hermeneutics. Hayek and Gadamer essentially agree on the fact that consciousness is the outcome of a process of interpretation that depends on a 'shifting horizon' - a hermeneutical horizon that is the product of history and that is subject to a constant evolution over time.

In order to compare Hayek and Gadamer, we will refer to the findings of the so-called enactive or neurophenomenological paradigm, which is a recent and improved version of Hayek's antiobjectivist connectionism (see Marsh 2010; see also Dupuy 2000, p. 66 ff.; Petitot 2002, p. 9 ff.). Like Hayek, theorists of this paradigm such as Maturana, Petitot, Thompson, and Varela argue that "perception is an act of interpretation" (Marsh 2010, p. 115) in the sense that the "world is not pregiven but enacted" in light of a certain historical context or past experience (Varela et al. 1991, p. 200). However, unlike Hayek, they underline that this idea mirrors "the tradition that includes hermeneutics and phenomenology" (Winograd 
and Flores 1987, p. 9). Consequently, their views are useful for building a bridge between Hayek and Gadamer. Both Hayek and enactivists combine an anti-essentialist epistemology with the theory that the mind is a complex self-organized system. Moreover, like Gadamer, Hayek and enactivists assign significant importance to the tacit or intuitive skills of man. Many aspects of the enactive approach are incompatible with the dominant Cartesian and objectivist paradigm in cognitive science (see Petitot et alt, 1999, p. 6 ff.). Especially the older versions of this paradigm - which is based on the so-called 'mind-computer analogy' - consider the mind to be a deterministic mechanism that adapts itself to objective and pre-given features of the environment (see Lachmann 2007, p. 42-43).

The paper is articulated into two parts. The first (Sections 1-3) focuses on the nature of knowledge, while the second (Sections 4 and 5) on that of action. Sections 1 and 2 show how Hayek's theory of sensory order is consistent with Gadamer's idea that knowledge is temporally conditioned interpretation. Section 3 links Hayek's view on socially distributed information to the hermeneutical aspects of his cognitive psychology. Section 4 argues that Hayek, like Gadamer, criticizes the mechanistic theories of action that deny that the individual is a free or autonomous being because they regard the individual as determined by the environment. Section 5 analyses the way Hayek defends the autonomy of man and methodological individualism by using his anti-objectivist connectionism which assumes that the mind is a complex self-organizing system.

\section{The Circular Causality between Consciousness and Experience}

Philosophical hermeneutics developed as a criticism of objectivism. According to objectivism, true knowledge is a neutral and specular representation of a pre-given world (see Gallagher and Zahavi, 2008 p. 15; p. 24). Gadamer (1977, p. 131-132) maintains that objectivism is wrong because we cannot know reality as it is in itself. Like Kant, he thinks that there is "a disproportion between form and essence” (Gadamer, 2006, p. 67). More precisely, Gadamer argues that we can know the world only by a selective interpretation - an interpretation in the light of historically variable and fallible a priori presuppositions. His outlook, as he acknowledges in his later works, is 
similar to Popper's anti-essentialist theory of truth (see Gadamer 1985, p. 495; Antiseri 2006, p. 31 ff.; Grondin 2003, p. 454). Popper (1980, p. 353) Popper agrees with Gadamer that their views are similar. Since Gadamer's philosophical hermeneutics is a fallibilist theory of knowledge, like classical hermeneutics, it is inconsistent with postmodernist epistemologies. Unlike what is often believed, Gadamer's position must not be confused with the relativist scepticism of authors such as Derrida, Kuhn and Rorty (See Di Iorio, 2013b).

Following Husserl and Heidegger, Gadamer points out that consciousness is based on tacit hermeneutical skills. These implicit skills build, through interpretation, our phenomenal world (for instance, the way we see colours). Since human beings are endowed with "hermeneutical" skills which cannot be expressed verbally, Gadamer maintains that the activity of mind cannot be reduced to pure and explicit reasoning. According to him, it is first and foremost “intuition” (Gadamer, 1977, p. 132; see also Marsh 2010).

Philosophical hermeneutics assumes that our knowledge is linked to an interpretative standpoint that is historical. This is what Gadamer calls a "horizon.” Criticizing the Cartesian approach and its objectivism, Gadamer argues that knowledge is not a construction "based on principles, but the furthering of an event that goes far back" (Gadamer, 1989 p. xxiv). The immediate experience is based on a past experience and will be, in turn, the presupposition that informs any future meanings we construct. "An experience is not ... just something that flows past quickly in the stream of conscious life" (p. 66). It is "not soon forgotten" (p. 67). It is part of a "unity of meaning" (p. 66). It is something that "immediately represents" a "whole," i.e. the whole that is composed of the history leading up to it and the future knowledge that will contribute to its shape (p. 70). Consequently, in Gadamer's opinion, the significance of an experience is not temporally limited but "infinite” (p.70).

This process of circular causality between experience and interpretative presuppositions of consciousness is characterised by the fact that new experiences always contain surprises and fail to meet our expectations. They are based on the unexpected. The "person who is situated and acts in history continually experiences the fact that nothing returns" (Gadamer 2006, p. 351). This awareness of the 
unpredictable "is always to be acquired, and from it no one can be exempt" (p. 350). So during his life, man "becomes aware of his finiteness" (p. 351). In the "real experience... are discovered the limits of the power and the self-knowledge of his planning reason" (Gadamer p. 351). Since there is a continuous restructuring of the individual interpretative horizon, this horizon is a shifting standpoint.

Given that knowledge is based on temporally variable a priori categories, there is a partial uniqueness of the individual interpretative presuppositions of experience. This depends on the non-coincidence between the histories of varied people. Because two different individuals cannot have an identical past, they cannot share exactly the same horizon. Consequently, they cannot see the world precisely in the same way:

"Everything that it is experienced is experienced by one-self, and part of its meaning is that it belongs to the unity of this self and thus contains an unmistakable and irreplaceable relation to the whole of this one life."

(Gadamer, 1989, p. 67)

\section{Memory and Sensory Order}

Although Hayek does not use Gadamer's lexicon, his cognitive psychology is consistent with Gadamer's hermeneutical theory of consciousness. Like Gadamer, Hayek argues that perception presupposes a particular historical standpoint - a horizon that is based on a fore-understanding.

"Every sensation must...be regarded as an interpretation of an event in the light of the past experience of the individual or the species."

(Hayek 1952, p. 166)

For Hayek, our phenomenal world is shaped both by genetically inherited and acquired Gestalt skills. So it is the product of a biological, personal, and cultural memory (see Nemo 1988, p. 44 ff.; see also Butos and Koppl 2006, p. 22-24). Given the connection between past experience and knowledge, perception does not mirror pre-given essences. The way Hayek conceives of perception can be viewed as "the continuous testing by the senses of educated hypotheses about the world around us" (Fuster 2003, p. 84). For Hayek, like for Gadamer and Popper, knowledge is based on "a 
concept far removed from the passive, receptive view of...the theory of the 'tabula rasa'” (p. 84; see also Butos and Koppl 2006, p. 43). Hayek is an anti-inductivist: all

\footnotetext{
"we know about the world is of the nature of theories and all 'experience' can do is to change these theories."
}

(Hayek, 1952, p. 143)

Hayek and Gadamer agree on the idea that consciousness is tacitly built by a know-how - a know-how we have accumulated along the way.

\footnotetext{
"We never act, and could never act in full consideration of all the facts of a particular situation, but always by singling out as relevant only some aspects of it.”
}

(Hayek 1983, p. 30)

However, we do so "not by conscious choice or deliberate selection, but by a mechanism over which we do not exercise deliberate control" (p. 30; see also Nemo 1988, p. 39 ff.; Petitot 2002; Smith 1997). In other words, the perception is "implicit... interpretation" (p. 143). The "sphere of mental phenomena is far more extensive than that of conscious phenomena" (p. 132). Conscious experiences can be "compared to mountain tops rising above the clouds which, while alone visible, presuppose an invisible substructure" (p. 139).

Like the hermeneutical a priori categories, Hayek's a priori categories are not only historical, but also continuously variable. Since the first draft of The Sensory Order, which was completed during the twenties and challenged various traditional psychological schools, (see Butos 2010), Hayek (1952, p. 142) criticized, the theory of pure sensations that "conceives of all mental events as being built up from fixed 'sensory' elements” (See also Hayek 1978, p. 38; Nadeau 1997, p. 9 ff.). The truth, he argued, is that all the aspects of sensory cognition are tacitly built and characterized by temporality and variability (see Caldwell 2004, p. 241 ff; Nadeau 1997, p. 5 ff.).

Fuster (1995 p. 87; 1997 p. 451) holds that Hayek has to be regarded as "the first to postulate what is the core" of contemporary theories, which consider the mind to be a dynamic and self-organizing system. Like the supporters of those more recent theories, Hayek links 
(at least implicitly) the study of mind to what enactivists like Van Gelder (1999, p. 315-340) and Varela (1999 p. 341-406) describe as typical phenomenological and hermeneutical issues. Like Gadamer, Hayek explains the mental activity in terms of a circular causality in the sense that he assumes the "perception as the source of memory and as the product of memory” (Fuster 1995, p. 87). In other words, Hayek and Gadamer agree on the following point: sensorial knowledge is created by memory; however, it affects the latter and partly changes it on the basis of a loop-back mechanism. In Hayek's opinion, the sensory order "is not a stable, but a variable order" (Hayek 1952, p. 19). The "structure of connexions in the nervous system is modified by every new action exercised upon it by the external world" (p. 123; see also Agonito 1975, p. 165, n. 16; Gray 1986; Smith 1997).

Hayek agrees with the hermeneutical theory that man is a finite being because of his temporality. Life, he writes, is a constant process of discovery of the unexpected and of variation in the presuppositions of cognition, generating a flux constituting that "continuum" which is "the 'I'" (Hayek 1952, p. 138; see also Nemo 1988, p. 50-52). The differences between the Hayekian theory of mind and the dominant computationalist paradigm in cognitive science, according to which there is an analogy between mind and computer, are evident. Especially the first versions of the computationalist paradigm assume that action depends on the representation of a given reality and on the mechanical implementation of an invariable set of limited instructions, which are pre-determined by a program. In Hayek's opinion, the mind, as a temporally conditioned hermeneutic device,

"will, as a result of its own operations, continuously change its structure and alter the range of operation of which it is capable. It will scarcely ever respond twice in exactly the same manner to the same external conditions. And it will as a result of 'experience' acquire the capacity of performing entirely new actions.”

(Hayek 1952, p. 122)

\section{Temporality of Consciousness and Distributed Knowledge}

According to Rizzo (2000, p. 175-180), the idea of the temporality of consciousness as intended by the phenomenological tradition is shared not only by Hayek, but by all the members of the Austrian School of Economics (See also O’Driscoll and Rizzo 1995, 
p. 52 ff.). The similarities between Hayek's theory of the sensory order and Gadamer's hermeneutics support the thesis that the Austrian approach is consistent with the phenomenological tradition. Moreover, both Hayek and Gadamer believe in the subjectivity of values.

As we have already pointed out, Gadamer thinks that, since the individual presuppositions of knowledge are historical, every consciousness is endowed with characteristics that are partly unique. Hayek's cognitive psychology matches up well this idea. The complete and specular correspondence of the interpretative sensorial presuppositions, Hayek (1952, p. 110) states, "would presuppose not only an identical history of the different individuals but also complete identity of their anatomical structure." This is impossible for Hayek. The mere fact that for each individual the mental categories "will be subject to constant changes practically precludes the possibility that at any moment" the sensory orders "of two individuals should be completely identical” (Ibid.). Since each sensory order does not mirror objective properties of the reality and since the way each individual interprets the reality is partly unique, it is impossible that all individuals share identical preferences. As Cubeddu (1995, p. 47-63) points out, Hayek's defends the subjectivist theory of value as intended by Austrian marginalist school from a neurophysiologic viewpoint. Like Gadamer, Hayek links the concept of value to the concepts of temporality of knowledge and non-identity of the personal histories.

As is well known, the subjectivism of values and distributed knowledge are intimately connected in Hayek's thinking. Reinterpreting Hayek's cognitive psychology in the light of Gadamer's hermeneutics helps us understand the sense in which Hayek believes that the information that is linked to "circumstances of the fleeting moment" cannot be centralized (Hayek 1992, p. 80; see also Butos \& McQuade 2005, p. 338; Marsh \& Onof 2008, p. 140144). For Hayek, the distribution of knowledge in society depends not only on the continuous and unpredictable change of the local circumstances, but also on the fact that each particular circumstance is interpreted by the individual who knows it in a way that is variable and partially unique. So what cannot be centralized and catalogued is not only the distributed knowledge of the circumstances, but also the different presuppositions of this knowledge because these 
presuppositions are variable like the circumstances. Due to the interaction between memory and experience, the continuous change of the circumstances influences our interpretative categories and makes our action largely unpredictable. Man’s “reason,” Hayek (1979, p. 176) writes, "always progresses by leading him into the unknown and unforeseen where he learns new things.” Because Hayek conceives of the mind in hermeneutical terms, his distributed knowledge is not an objective knowledge, i.e. a knowledge that is unrelated to the problem of interpretation (see Di Iorio 2010, p. 196-197; Rizzello 1999).

\section{Interpretation as Preservation of Autonomy}

Another relevant point on which Hayek and Gadamer agree is the idea that human action, due to its hermeneutical presuppositions, cannot be explained as passive adaptation to objective and given properties of reality. As Gadamer points out, since man is an interpreter, his "relationship to the world is characterized by freedom from environment” (Gadamer 2006, p. 441).

"Life is defined by the fact that what is alive differentiates itself from the world in which it lives and which it remains connected, and preserves itself in this differentiation."

Gadamer (2006, p. 243-244)

Since the world exists only as an a priori construction, i.e. as meaning, action is not affected by external factors that can be regarded as 'essences' or 'data.' The way the world is seen, which is temporally changeable, is the "free expression of an individual being" (p. 187). This point should not be misinterpreted. Neither Gadamer nor Hayek defends a kind of solipsism. Following the transcendental approach, Gadamer does not criticize realism. He only rejects the so-called naive or essentialist realism. According to his hermeneutical theory of knowledge, the dichotomy between life and world is not absolute in the sense that it implies that action is not linked at all to the structure of the world.

"What is alive preserves itself by drawing into itself everything that is outside it. Everything that is alive nourishes itself on what is alien to it. The fundamental fact of being alive is assimilation. Differentiation, then, is at the same time non-differentiation. The alien is appropriated.”

(Gadamer 2006, p. 244) 
It is hermeneutically appropriated.

The theorists of the enactive paradigm, who share the same connectionist and anti-essentialist conception of perception as Hayek, argued that if the mind works like Hayek thinks it does, what Gadamer calls "freedom from the environment" is "a fundamental characteristic" of the human being (Thompson 2007, p. 15). The work of the enactivists helps us understand the philosophical implications of Hayek's cognitive psychology and the similarities between Hayek's and Gadamer's views - similarities that Hayek never acknowledged. Criticizing the representationalist paradigm, which is dominant in cognitive science, enactivists maintain that the activity of the mental system as understood by Hayek implies the co-emergence of the consciousness and its world (see Besnier 2005, p. 84). This means that the mind, instead of mirroring nature, is able "to enact a world," i.e. to build a world by interpretation in light of a specific history and through tacit skills (Varela et al. 1991, p. 151). According to enactivists, it is ultimately the way the external reality is enacted that produces action and makes the human mind an autonomous system, where autonomy means "freedom from the environment" in the sense of Gadamer.

A logical machine like a computer does adapt itself to "a picture of the relevant surroundings" (Varela 1979, p. XVI). Consequently, the cause of its behaviour is outside of it. A computer works according to a principle that can be called, as Varela (p. XI) states, "allonomy or external law." An autonomous system like mind is, on the contrary, an interpretative device; autonomy "means, literally, self-law" (p. XI). It is the opposite of control, predetermination, mechanical adaptation, programming, and instruction. It instead means "generation, internal regulation, assertion of one's own identity: definition from inside” (p. XII). The cause of the behaviour of a system endowed with autonomy is inside of it (see Maturana and Varela 1980; Thompson 2007, p. 4344).

In accordance with the enactivist and anti-representaionalist view, Hayek remarks that our behaviour must not be regarded as predetermined by the context. 
"[A] mechanism or mechanical process....is essentially passive, in the sense that which of the different operations of which is capable it will perform will depend exclusively on the external circumstances."

(Hayek 1952, p. 122)

On the contrary, a dynamic system that develops interpretations of the environment as the human mind does "will show opposite characteristics" (Hayek 1952, p. 122). In other words, its

“actions will appear self-adaptive and purposive, and it will in general be 'active' in the sense that what at any given moment will determine the character of its operation will be the pre-existing state of its internal processes as much as the external influences acting on it.”

(Hayek 1952, p. 122-123)

\section{A Defence of Verstehen through the Complexity Theory}

Hayek links an anti-essentialism theory of knowledge in the sense of Gadamer to a connectionist theory of mind. According to the Hayekian connectionism, like the market, mind is "a complex dynamic system” - a self-organizing system (Hayek 1952, p. 109; see also Butos \& McQuade, p. 336-338; Di Iorio 2010; Smith 1997, p. 9 ff.). Unlike a computer, mind is not a system endowed with a central unit that controls a set of components following a program.

Like Hebb (1949), Hayek assumes that neurons build up the perceptive categorizations by a sort of spontaneous cooperation. This cooperation is made possible by the fact that neurons function according to some rules of activation and interaction (Hayek 1952, p. 53; see also Butos and McQuade, 2005; Marsh \& Onof, 2008; Smith 1997; Varela 1979; Weimer 1982, p. 245). In Hayek’s opinion, when appropriately connected, the neurons "have interesting global properties” (Varela et al. 1979, p. 87). This explains the emergence of our phenomenal world, i.e. of our consciousness (see also Butos and Koppl 2006, p. 32). From this connectionist perspective, the theory "of structural properties as distinct from the properties of the elements" is not only useful for understanding the gestalt-nature of cognition; it "is directly applicable" to the explanation of the functioning of our nervous system (Hayek 1952, p. 47). Since the Hayekian mind is a temporally conditioned 'hermeneutic device,' the 
behaviour of neurons is not only affected by some rules of interaction and by the external stimuli, but also by the history of past cooperation among the different neurons. In addition, the way neurons interact ensures a continuous learning process (see Érdi 1996, p. 187).

If the mind is a self-organizing system as argued by Hayek, perception is not a deterministic (in the sense of predictable) process that can be explained in monocausal terms like the old objectivist theories of perception assume. According to an old mechanistic view, perception presupposes a specific object, understood as a given datum, which is the single cause - the stimulus - triggering a representation. This representation is supposed to be mirroring the object and is considered to be connected to a typical and predetermined behaviour.

Hayek disagrees with this view. First of all, he maintains that perception never depends on a single stimulus, but always on groups of stimuli (Hayek 1952, p. 25 ff.). Moreover, he points out, although more implicitly than explicitly, that action cannot be described in deterministic terms because perfect and detailed scientific previsions require closed systems. Since a complex system like the human mind is a very open system, it is characterized by a continuous and unpredictable change of the initial conditions of the explanation. This makes prediction difficult because applying the ceteris paribus clause is problematic. The continuous change of the initial conditions depends both on the unexpected external events that affect the structure of the neuronal interactions and on the lack of a central unity that coordinates the different neurons. Because the neurons are characterized by operative independence, they can constantly and unpredictably modify their state (Hayek 1952 p. 185 ff.; 1967 p. 55 ff.; see also Caldwell 2004 p. 363; Di Nuoscio 2006, p. 46-48; Dupuy, 1990; Marsh 2010, p. 140-141; Nadeau 2001, p. 67 ff.; Petitot, 2002). Hayek links the old hermeneutical idea that consciousness presupposes a "shifting horizon" to a theory of complexity - a theory that gives, like Gadamer's philosophy, great importance to the notions of time and change.

Hayek's analysis of the connections between complexity and unpredictability of action is relevant from the standpoint of the epistemology of social sciences. His cognitive psychology must be regarded as a defence of methodological individualism because, unlike various anti-individualist paradigms, it rules out the possibility 
of conceiving of action in deterministic terms. Hayek's connectionism is consistent with the idea that man is a free being in the sense that the causes of his actions cannot be lodged in the environment. If the human mind is an open and non-deterministic system, action cannot be explained as a by-product of objective external constraints. Even though

"we may know the general principle by which all human action is causally determined..., this would not mean that to us a particular human action can ever be recognizable as the necessary result of a particular set of...circumstances.”

(Hayek 1952, p. 193)

Like Gadamer's hermeneutics, Hayek's The Sensory Order is supportive of Verstehen (interpretative approach) in social sciences. According to Hayek, the ultimate causes of social phenomena must be sought in the meaning the individuals attach to their actions rather than in alleged objective constraints (see Boettke 1990, p. $36 \mathrm{ff}$, Butos \& Koppl 2006, p. 22-22; Caldwell 2004, p. 247; 2007, p. 260; Di Iorio 2009; 2010, p. 179 ff; 2013a; Koppl; 2008, p. 38; 2010).

\section{REFERENCES}

Agonito, R. (1975), “Hayek Revisited: Mind as a Process of Classification”, Behaviorism: A Forum for Critical Discussions, Vol. 3, No. 2, pp. 162-171.

Antiseri, D. (2006), «Epistemology and Hermeneutics », in Alai M. \& Tarozzi G. Karl Popper Philosopher of Science, Rubettino, Soveria Mannelli, pp. 31-53.

Barthelemy, J-P., De Glas, M., Descles, J-P. and Petitot J. (1996), « Logique et dinamique de la cognition”, Intellecta, Vol. 2, No. 23.

Besnier, J-M. (2005), Les théories de la connaissance, Puf, Paris.

Boettke, P. J. (1990), “Interpretative Reasoning and the Study of Social Life”, Methodus, vol. 2, No. 2.

Butos W. N. and McQuade T. (2005), "The Sensory Order and Other Adaptive Classifyng Systems”, Journal of Bioeconomics, Vol. 7, 335-358.

Butos W. N. and Koppl R. G. (2006), "Does the Sensory Order Have a Useful Economic Future?”, in E. Krecke and K. Krecke (Eds.), Advances in Austrian Economics, Vol. 8, JAI Press, Oxford. 
Butos, W.N. (2010), “The Unexpected Fertility of Hayek's cognitive Theory: an Introduction to The Social Science of Hayek's The Sensory Order" in Butos, W.N (Ed.) Advances in Austrian Economics, vol. 13, 1-20.

Caldwell, B. (2004), “Some Reflections on F.A. Hayek’s The Sensory Order, Journal of Bioeconomics, 6, pp. 239-254.

Caldwell, B. (2007), Hayek's Challenge. An Intellectual Biography of F. A. Hayek, The University of Chicago Press, Chicago.

Cubeddu, R. (1995), Friedrich A. Von Hayek, Quaderni del centro di Metodologia delle Scienze Sociali Luiss, Borla, Roma.

De Vecchi, N. (2003), “The Place of Gestalt Psychology in the Making of Hayek’s Thought”, History of Political Economy, Vol. 35, No. 1.

Di Iorio, F. (2009), "Hayek’s Connectionist Psychology as a Defense for the Sociology of Good Reasons" in M. Cherkaoui and P. Hamilton Raymond Boudon. A Life in Sociology. Essays in Honour of Raymond Boudon, 4 volumes, The Bardwell Press, UK.

Di Iorio (2010), "The Sensory Order and the Neurophisiological Basics of Methodological Individualism” in W. N. Butos, The Social Science of Hayek's 'The Sensory Order', Emerald, Bingley, Uk.

Di Iorio (2013a), “Cognitive Autonomy and Epistemology of Action in Hayek’s and MerleauPonty's Thought” in R. Frantz and R. Leeson (eds.) Hayek and Behavioural Economics (with a foreword by Vernon Smith), Palgrave Macmillan.

Di Iorio (2013b), “Are Hermeneutics and the Austrian Approach Compatible? A Clarifying Analysis”, CHOPE Working Paper No. 2013-06.

Di Nuoscio, E. (2006), Il mestiere dello scienziato sociale. Un'introduzione all'epistemologia delle scienze sociali, Liguori, Napoli.

Dreyfus, H. L. and Dreyfus, S. E. (2000), Mind Over Machine. The Power of Human Intuition and Expertise in the Era of Computer. Paper Back, New York.

Dupuy, J-P. (1990), Ordres et désordres. Enquête sur un nouveau paradigme, Seuil, Paris.

Dupuy, J-P. (2000), The Mechanization of Mind. On the Origins of Cognitive Science, Princeton University Press, Princeton and Oxford.

Érdi P. (1996), “The brain as a Hermeneutic Device”, BioSystems, 38, pp. 179-189.

Fuster, J. (1995), Memory in the Cerebral Cortex: An Empirical Approach to Networks in the Human and Nonhuman Primate, The MIT Press, Cambridge, MA.

Fuster, J. (2003), Cortex and mind: unifying cognition, Oxford University Press, Oxford.

Gallagher, S. \& Zahavi D. (2008), The Phenomenological Mind: An Introduction to Philosophy of Mind and Cognitive Science, Routledge, London.

Gadamer H-G., (1981), Reason in the Age of Science, The MIT Press, Cambridge, MA.

Gadamer H-G., (1997), Philosophical Hermeneutics, University of California Press, BerkleyLos Angeles-London. 
Gadamer H-G. (2003), A Century of Philosophy. A Conversation with Riccardo Dottori, Continuum, London \& New York.

Gadamer H.-G. (2006), Truth and Method, Continuum, London \& New York.

Gadamer H-G. (2007), The Gadamer Reader. A Bouquet of the Later Writings, Northwestern University Press, Evanston, Illinois.

Gray, J. (1986), Hayek on Liberty, Oxford, Blackwell.

Grondin, J. (2006), L’Herméneutique, Puf, Paris.

Hayek, F. A. (1948), Individualism and Economic Order, The University of Chicago Press, Chicago.

Hayek, F. A. (1952), The Sensory Order. An Inquiry into the Foundations of Theoretical Psychology, Routledge \& Kegan Paul Ltd, London:

Hayek, F. A. (1952a), The Counter-Revolution of Science Studies on the Abuse of Reason Liberty Press, Indianapolis.

Hayek, F. A. (1967), Studies in Philosophy, Politics and Economics, The University of Chicago Press, Chicago.

Hayek, F. A. (1973), Rules and Order, Vol. 1 of Law, Legislation and Liberty, University of Chicago Press, Chicago.

Hayek, F. A. (1978), New Studies in Philosophy, Politics, Economics and the History of Ideas, Routledge \& Kegan Paul, London.

Hayek, F. A. (1994), Hayek on Hayek. An Autobiographical Dialog, The University of Chicago Press, Chicago.

Hebb, D. O. (1949), The Organization of the Behavior, Wiley, New York.

Koppl R. (2010), “Some Epistemological Implications of Computational Complexity”, Journal of Economic Behavior \& Organization, pp. 859-872.

Koppl R. (2008), "Scientific Hermeneutics: a Tale of Two Hayeks” in Advances in Austrian Economics, vol. 11, pp. 99-122.

Lavoie D. (Ed.) (1991), Economics and Hermeneutics, Routledge, London and New York.

Marsh L. (2010), "Hayek: Cognitive Scientist Avant la Lettre. Advances”, Advances in Austrian Economics, Volume: 13 Page: 115 - 155.

Marsh L. \& Onof C. (2008), “Stigmergic Epistemology, Stigmergic Cognition”, Cognitive Systems Research 9, 136-149.

Maturana, H. R. \& Varela F. J. (1980), Autopoiesis and Cognition. The Realization of the Living, Reidel Publishing Company, Dordrecht, D.

Maturana H. R. e Varela F. J. (1988), The Tree of Knowledge. The Biological Roots of Human Understanding, Shambhala Publications, Boston, MA. 
Nadeau, R. (1997), Hayek and the Complex Affair of the Mind, Sixty-seventh Annual Conference of the Southern Economic Association. Atlanta, Georgia, November 21-23.

Nadeau, R. (2001), Sur l'antiphysicalisme de Hayek. Essai d'élucidation, Revue de Philosophie Economique, No. 3, vol 1, p. 67-112.

Nemo, P. (1988), La société de droit selon Hayek, Puf, Paris.

O’Driscoll G. P. and M. J. Rizzo (1995), The Economics of Time and Ignorance, Blackwell, Oxford and New York.

Petitot J., Varela J. F., Pachoud B., Roy J-M. (1999), Beyond the Gap : An Introduction to Naturalizing Phenomenology in Petitot J., Varela J. F., Pachoud B., Roy J-M. (Eds.), Naturalizing Phenomenology. Issues in Contemporary Phenomenology and Cognitive Science, Stanford University Press, Stanford, California.

Petitot J. (2002), "Vers des lumières hayekiennes: de la critique du rationalisme constructiviste è un nouveau rationalisme critique", A. Leroux et R. Nadeau (Eds), Friedrich Hayek et la philosophie économique, Philosophie économique, Colloque de Cerisy, No. 2.

Petitot J. (2003), "Morphodynamical enaction: the case of color", Biological Research, A Tribute to Francisco Varela (J. Bacigalupo, A.G. Palacios eds.), 36, 1, p. 107-112.

Popper, K-R. (1980), “Autointerpretazione filosofica e polemica contro i dialettici” in Grossner C. (ed.) I filosofi tedeschi contemporanei (Verfall der philosophie. Politik deutscher Philosophen), Città nuova, Roma.

Rizzello, S. (1999), The Economics of Mind. Edward Elgar, 1999, Northampton, Ma.

Rizzo, M.J. (2000), "Real Time and Relative Indeterminacy in Economic Theory" in Baert P. (Ed.), Time in Contemporary Intellectual Thought. Elsevier Science, 173-188.

Smith, B. (1997), “The Connectionist Mind: A Study of Hayekian Psychology” in S. F. Frowen (Ed.), Hayek Economist and Social Philosopher: A Critical Retrospect, McMillan, London.

Thompson E. (2007), Mind in Life: Biology, Phenomenology, and the Sciences of Mind, Harvard University Press, Cambridge, MA.

Varela, F. J. (1979), Principles of Biological Autonomy, Elsevier, North-Holland, New York.

Varela, F. J. (1989a), Connaître les sciences cognitives. Tendances et Perspectives. Seuil, Paris.

Varela F. J. (1989b), Autonomie et Connaissance. Essai sur le vivant, Seuil, Paris.

Varela F., Thompson E. and Rosch E. (1991), The Embodied Mind. Cognitive Science and Human Experience, The Mit Press, Cambridge, MA.

Winograd, T. and Flores, F. (1987), Understanding Computers and Cognition. A New Foundation for Design, Ablex Corporation, Norwood, NJ. 